\title{
Exploring the role of archaeology within Indigenous natural resource management: A case study from Western Australia
}

\author{
David Guilfoyle, Applied Archaeology, Albany, Australia \\ Myles Mitchell, Applied Archaeology, Albany, The Australian National University, Australia \\ Cat Morgan, Applied Archaeology, Albany, Australia, University of Leicester, United Kingdom \\ Harley Coyne, Department of Indigenous Affairs, Southern Regional Office, WA, Australia \\ Vernice Gillies, Albany Heritage Reference Group Aboriginal Corporation, Australia
}

\section{Introduction and background context}

For Indigenous archaeology, an important measure of 'success' within any project is the level of control and ownership embedded with the local Traditional Owner community. If control/ ownership is tokenistic, short-term, or undeveloped, archaeological research outcomes remain limited by default - in the understanding that Indigenous heritage management is linked to community identity and wellbeing, and requires delivery under customary practice/protocols. Any level of archaeological research - whether community, research or commercial - requires systems to ensure Traditional Owners are in control of all facets of project development, implementation, and reporting, at the level and context that they demand.

This paper outlines the results of a community heritage management project centred on a property bordering Lake Pleasant View, at Many Peaks, southwestern Western Australia (Figure 1). The focus here is on the role of archaeology and archaeologists in the design and implementation of the project as led and guided by the local Traditional Owners. The project was originally established as an Indigenous Cultural Heritage Management (ICHM) plan within a broader Natural Resource Management (NRM) project for a wetland under threat from natural and human processes (Guilfoyle et al. 2009). An outcome of this programme has been the acquisition of resources in securing a property vested with a Traditional Owner community organisation, that includes a long-term research programme examining the wider archaeological landscape centred around this wetland, and delivering an integrated conservation and management plan. For each stage of this project, an NRM/ICHM model was developed that drew heavily from, and integrated, a diverse body of theory within community, Indigenous and landscape archaeology.

This project was based on the recognition that effective Indigenous cultural heritage management requires protecting and managing both the physical fabric of places and landscapes, as well 
as the associated values related to community-identified social and cultural activity (Byrne et al. 2003). In so doing, structures are required to enable these activities to take place, and this necessarily involves moving beyond the assessment or identification of values, and to embedding a mechanism that allows social and cultural activity to take place. Although there are many facets of this dynamic project, this paper focuses on the role of archaeology in embedding community ownership and control of an area for effective management. It is suggested that a significant mechanism for linking diverse fields of archaeology may be found in the integration with methods and objectives that lie within NRM.

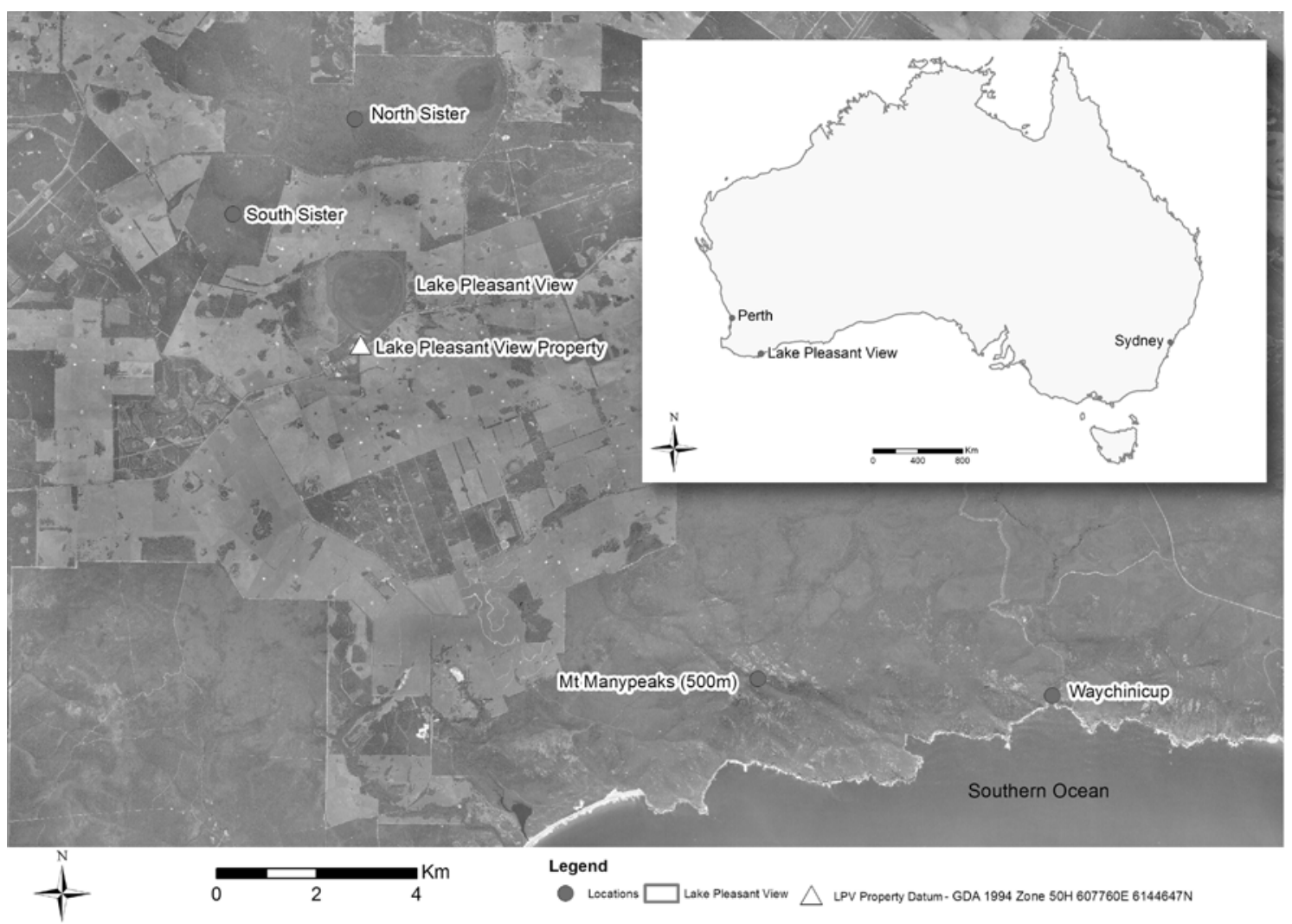

Figure 1. Location map.

Source: Image supplied by Gondwana Link.

\section{The place}

The area is dominated by a wetland surrounded by a narrow nature reserve managed by the Department of Environment and Conservation (DEC), and is listed as a Wetland of National Significance (Environment Australia 2001). The moderate-sized sedge lake (201 ha) comprises small open areas and extensive areas of sparse sedge. The wetland lies within the Albany-Fraser Orogen geological formation, bounded in the north by the older Yilgarn Craton, somewhat neatly divided by the Stirling Ranges. The major south coast river systems of the Albany area (King and Kalgan) formed during a southward down-tilting of the Yilgarn Craton, creating an extensive slope known as the Ravensthorpe Ramp, and much of the region was inundated by higher sea levels during the Eocene Age. As a result of these processes, the short rivers were formed and vast sand plains filled with Tertiary sediments were created, forming a low relief plain dotted with small wetlands, with the basement geology visible in various areas as impressive granite domes, such as Mount Clarence, Mount Lindsay, the Porongurup Range and the North and South Sister hills that surround the wetland. 
The area is an important cultural area for the Traditional Owners and creates a 'sense of place' because of its associated oral histories, cultural features, and aesthetic values provided by the striking landform configurations. A Dreaming Story describes the creation of the wetlands - Lake Pleasant View - and surrounding wetlands and associations with the prominent, surrounding hills (Figure 2).

This place here, we call Moolyiup, the hill that you see behind me is Moolyiup, and the one behind her is Twertup, they are two sisters. They belong to the kangaroo people - which are the Stirling's (ranges to the north). We call all this area Moolyiup. They were promised to the same man, that came from down Cape Riche way (south coast), and he travelled up to where the kangaroo people were, picked his two brides out, which happened to be the two sisters, and taken them back down to Warriup, and when they got so far they realised that the fellow that picked them, the bloke that married them was the devil himself Chunuk. The Chunuk lived over at Warriup and they stopped in their tracks when they realised, and they had a bit of a chat and said look we gotta make a run for it. So they ran straight up the foot range over there - they represent the devils footsteps as he followed them along, and he caught them here and their mother is Yoolberup, which is the peak behind you - Mount Manypeaks, her name is Yoolberup. Before they got there he caught them here and turned them to stone. The lake systems themselves were what the Devil left behind, his footsteps - and the water that you see in the lakes system, the entire lakes system, are the tears from those two girls. (Aunty Lynette Knapp, pers. comm., 2010)

The area has continued to be used by the local Traditional Owners (Menang People) throughout the post-contact period. In the earliest days of settlement, such areas provided a 'refuge' for accessing traditional resources and maintaining traditions in a context of increasing segmentation of the landscape into farming properties, as the region's European population increased and restricted patterns of traditional movement and settlement. During the 1950s members of nearly all families from the region utilised this area on a regular basis and well-known individuals from the community set up camps along the edges of Lake Pleasant View, using the wetland's resources. Today, individuals and families use the area for spiritual reflection and passing of their knowledge to their youngsters. Thus, the area is of important historical association and enhances cultural connections today.

There is a small area of private land that borders the southern edge of the wetland. On this property, a large granite dome dominates, providing 360 degree views of the vast sedge land, tall woodland, majestic hills, and surrounding open pasture. The associated archaeological landscape includes artefact scatters that occur throughout the property, the adjacent nature reserve, and exposed areas along various access tracks. Gnamma (water) holes were also located and recorded on the granite hill that extends to the neighbouring reserve to the west. Loose slabs of granite (now removed from this area) presumably functioned as lizard traps. Indeed lizard traps recorded previously can no longer be found, and so have presumably been destroyed by quarrying (discussed below). A putative modified (scarred) tree is also located on the site. The property and reserve also contain historical significance as a place where Menang people camped and hunted throughout the 1950s and 1960s.

The granite dome that dominates the property in question has been subject to major destruction by the previous landholder, as part of past quarrying activities. This includes the complete destruction of a rockshelter that was an important component of the archaeological and cultural landscape (Figure 2). These destructive activities represent past failures of compliance-based heritage legislation in protecting a significant cultural place that is a component part in an 
extended cultural landscape. While the past legislative failures to protect these cultural resources are not the focus of this paper, they provide an important background as the impetus to effect positive outcomes for cultural heritage values at this place.

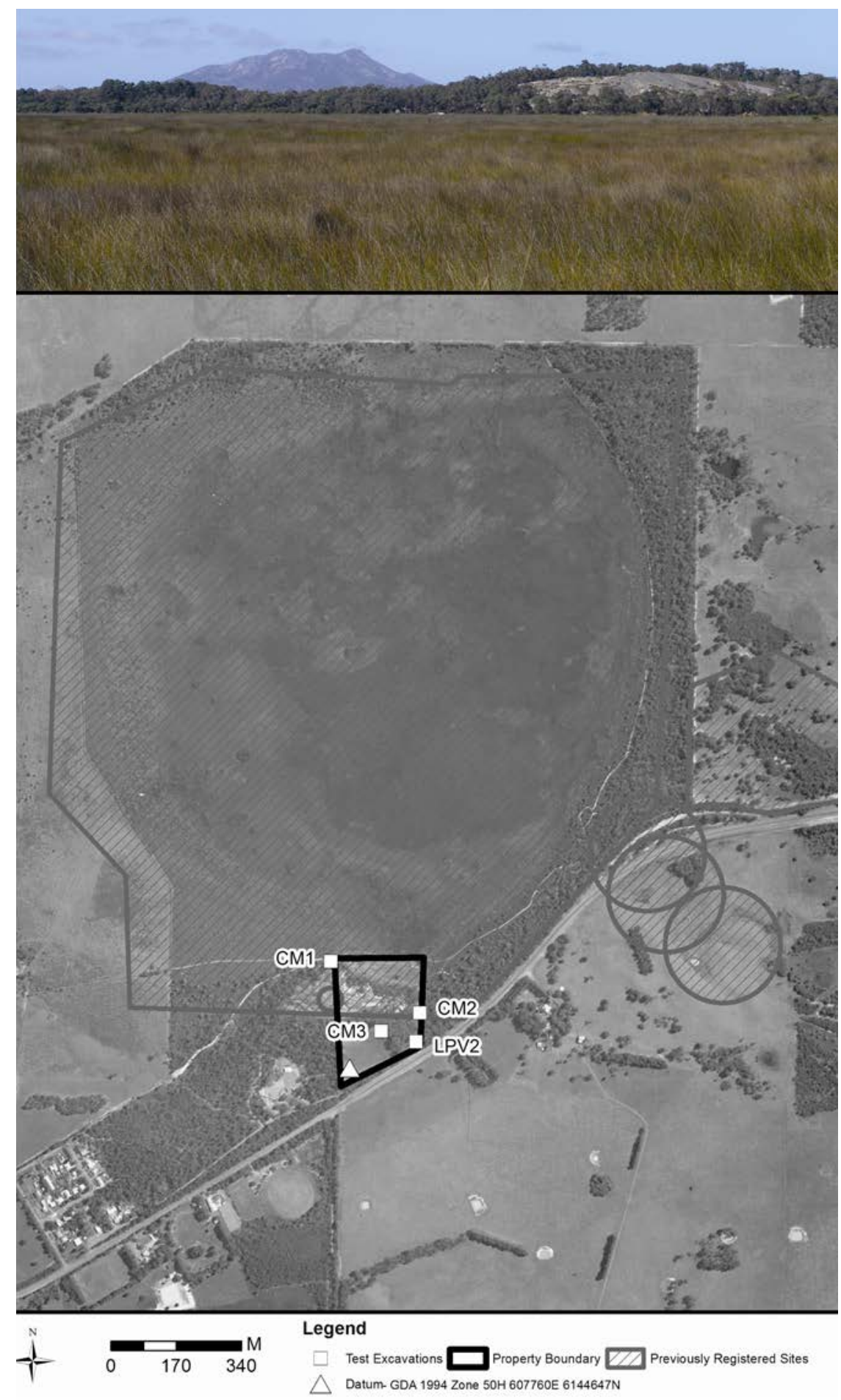

Figure 2. Map of the property, Lake Pleasant View, registered sites, and test excavations. Photo insert is a view south from the middle of the Lake to the granite dome (within the community-owned property) and Mount Many Peaks in the background.

Source: Image supplied by Gondwana Link. 
The property has contemporary social significance as an area that should be restored and used for cultural activity and education. Active conservation continues to be carried out on the property as it is now managed by the local Menang community and a variety of partners as outlined below. The Menang Traditional Owners articulated the importance of caring for Country, as part of this project:

The 'mountains' and the 'hills' you see, we call them kart, we also call our 'heads' kart, so that's the relationship. And 'water' is beelia, beel when it is still water like this (pointing to Lake Pleasant View) or beelia is running water. We also call our mothers, when they nurse us and their milk is running, that is beelia, so that is a part of us. We cherish and respect, when we are on Country, particularly walking in the bush. Kart, 'the hills', they've got eyes like we have, so they watch our every move. Which is why we respect our Country, we can't do anything wrong on our Country, we got to respect it and we got to look after our Country (Aunty Lynette Knapp, pers. comm., 2010).

Thus, from the outset, this project involved establishing a structure that integrated an assessment of the values associated with this area and also for ongoing management of the area under traditional concepts of 'caring for Country'. Both the natural and cultural values of this area have been degraded and were under threat from neglect, poor land-planning, and direct vandalism. The lake system is threatened by eutrophication resulting from agricultural and plantation fertilisers. The spread of non-native flora and fauna species was uncontrolled. Illegal rubbish dumping has taken place along the eastern edge of the lake. The previous landowner has damaged many heritage features associated with the granite outcrop. Sheep have grazed over the property and across culturally sensitive areas. Natural bush land has been cleared, including cultural plants. Quarrying and clearing have damaged natural and cultural heritage features.

The next section discusses the integrated archaeological framework that served to structure the way this project was developed and implemented, based on a review of the key stages/components of the project. This precedes a discussion that examines the wider implications drawn from this analysis in terms of the role of archaeology in the dynamic field of Indigenous cultural heritage management and NRM.

\section{Cultural heritage ownership and the integration of archaeology}

This project was implemented under an integrated model that served to overcome some of the limitations of narrowly-defined compliance based CRM processes, within a philosophy to work beyond compliance to a more integrated community archaeology model, as reflected in this statement:

There is a genuine desire by many heritage professionals, despite legislative constraints, to work towards a cultural heritage practice that supports the integration of archaeology, cultural heritage and Indigenous knowledge. (Pragnell et al. 2010:152)

The limitations within compliance-based CRM processes are well documented; with reference to inadequate integration of traditional owner values and knowledge (Brown 2008; Hemming and Rigney 2010; Guilfoyle et al. 2011), a lack of integration into meaningful research paradigms (Morse 2009), limitations of relevant legislative mechanisms including the Australian National Heritage listing process (Sullivan 2008) and the Western Australian Aboriginal Heritage Act 1972 (Anaya 2010), and relevant inadequacies in teaching and learning practices with regard to professionalism in Australian archaeology and CRM (Colley 2007). It is particularly noteworthy that James Anaya - United Nations (UN) Special Rapporteur on the Rights of Indigenous Peoples - made specific mention of the Western Australia Aboriginal Heritage Act as a point of 
concern in a report to the UN General Assembly, 1st June 2010 (Anaya 2010). Within this context of identified weaknesses in CRM processes, this project aimed to raise the bar above minimum standards and achieve outcomes for the protection and management of an important cultural place, attaining tangible community/social outcomes through all stages of the project. This required consideration of the need to integrate diverse archaeological frameworks and methods with Aboriginal values and knowledge, adopting a framework similar to that espoused by Prangell et al. (2010), in which power relations are renegotiated through a community-led, landscape based approach. This section examines each of the main stages/components of the project in relation to the adopted archaeological framework.

\section{Land access and land ownership}

Following community meetings set up initially to address the impacts caused to the registered heritage site by the previous landowner, the local Elders expressed their desire to obtain access to actively use, restore and manage the entire wetland area. These suggestions became the impetus for management that necessarily involved legal access to the area, and a subsequent land purchase application. The purchase of the 6 ha parcel of land was funded by the Indigenous Land Corporation (ILC) in 2005 for the Albany Heritage Reference Group Aboriginal Corporation (AHRGAC). The AHRGAC is comprised of Elders, Traditional Owners, and representatives of all Noongar families with historical, social, cultural and spiritual attachments to the Albany region and surrounding hinterland. The main purpose of the AHRGAC is to provide guidance on all matters affecting Noongar cultural heritage in the region. The Department of Indigenous Affairs (Southern Region, WA) works closely with the AHRGAC and provides support to facilitate the cultural use of this and other areas of land.

The land acquisition application was developed by (co-authors) Guilfoyle and Coyne (see Guilfoyle et al. 2009), following a site disturbance investigation involving quarrying of the large granite outcrop (and registered archaeological site) by the previous landowner. Because the property had been privately owned for many years, it had been difficult to access for cultural activities. Thus, following several field visits and planning sessions, one of the first actions was to draft a purchase application, which was submitted on behalf of the Reference Group. The result was a successful submission to the Indigenous Land Corporation in 2005 enabling the Reference Group to purchase the property.

This acquisition was the most direct form of ownership and control in the short-term but the integrated team also established a mechanism for ongoing community control of the management processes, and through all facets of this 'project'. Aplin (2002) has argued that ownership of heritage must move beyond tokenistic recognition, and also involve 'ownership' of the process that includes: "research, the development of listing proposals, the preparation of conservation and management plans, interpretation, and sharing financial rewards where they occur" (Aplin 2002:140).

In order to ensure these objectives, and for the land acquisition and subsequent management programme to be successful, a well-planned structure was required. This necessarily involves extensive planning, and in this case, the development of the incorporated body made up of community members that could manage the property - the AHRGAC. From here, a three-way collaborative agreement was established between AHRGAC, representatives from the Restoring Connections Project (South Coast Natural Resource Management Inc.), and the Department of Indigenous Affairs (Albany region). This process and partnership structure was set up to ensure that there were sufficient integrative mechanisms in place to deliver the ongoing management requirements of the property. It has been well argued that collaborative partnerships are critical to 
long-term sustainability of any community archaeology or CRM project (Moser et al. 2002:229) and it was partnerships that underpinned the ultimate success of this project. Restrictions in national parks, reserves, and private land mean that the land area for local Traditional Owners to continue cultural practices, such as obtaining wild resources and being on land in a traditional manner, is quite low. This creates an impetus to work towards attaining access, and ultimately ownership of land for cultural purposes, which was the basis of this project.

\section{Management action plan: Heritage as social action}

Another critical component centered on the need to ensure that the management process for the wetland and heritage landscape would be driven by the local community, to 'manage and protect country'. The premise was that heritage should be seen as a cultural and social activity, and it is only through such activity that vibrant cultural connections can be maintained (Byrne et al. 2003). The archaeologist, heritage officers and Traditional Owners involved in this project knew that the project must address this understanding in order to achieve any level of success, and so each component must serve to address this aspect of cultural heritage management. There is increasing recognition of the importance of heritage in matters of Indigenous identity and wellbeing, for example:

Our acceptance that heritage helps to define identity and express values and aspirations, means we must be concerned about the conservation of Australia's Indigenous heritage. There is a fragile grasp on the management of Indigenous culture, which is integral to the identity and well-being of Australian Indigenous peoples. (Open Mind Research Group 2006:3)

Direct links have been drawn between the maintenance of culture, heritage and traditional lands, with Indigenous health in Australia and elsewhere; and NRM is posited as a key mechanism for delivering direct and indirect health-related outcomes for Indigenous communities (Burgess et al. 2005):

Effective interventions in Indigenous health will require trans-disciplinary, holistic approaches that explicitly incorporate Indigenous health beliefs and engage with the social and cultural drivers of health. Aboriginal peoples maintain a strong belief that continued association with and caring for ancestral lands is a key determinant of health. Individual engagement with 'Country' provides opportunities for physical activity and improved diet as well as boosting individual autonomy and self-esteem. Internationally, such culturally congruent health promotion activities have been successful in programs targeting substance abuse and chronic diseases. (Burgess et al. 2005:117)

This community archaeology program aimed to achieve outcomes in identity, well-being and health, through the promotion and effective management of cultural heritage values. As such, a heritage management plan was developed which resulted in securing of funds for community members to carry out 'management actions' that included a range of components - including social gatherings, weed control, educational trips, and training courses. This plan was endorsed by the Indigenous Land Corporation and the DIA (Guilfoyle 2010). It is interesting to note that it was the incorporation of the cultural heritage values associated with this area that led to the development of the management plan for the wetlands. Despite its ecological and cultural heritage significance, no management plan existed for the Lake Pleasant View Nature Reserve. At the same time, much of the CRM activity implemented in the past in this region, and at this site in particular, has been reactive rather than strategic - focused on identifying options to protect a site (such as the now destroyed rockshelter) from imminent threat. Thus, it was clear that an effective heritage management system for this place must explore management at a landscape level, and in contexts outside of development-driven (or site-threat) proposals. In so doing it was necessary to work beyond the basic legislative requirements focused on assessment, and to link both NRM and CRM objectives. These principles are vital if CRM is to contribute to any sense of community wellbeing. 
A

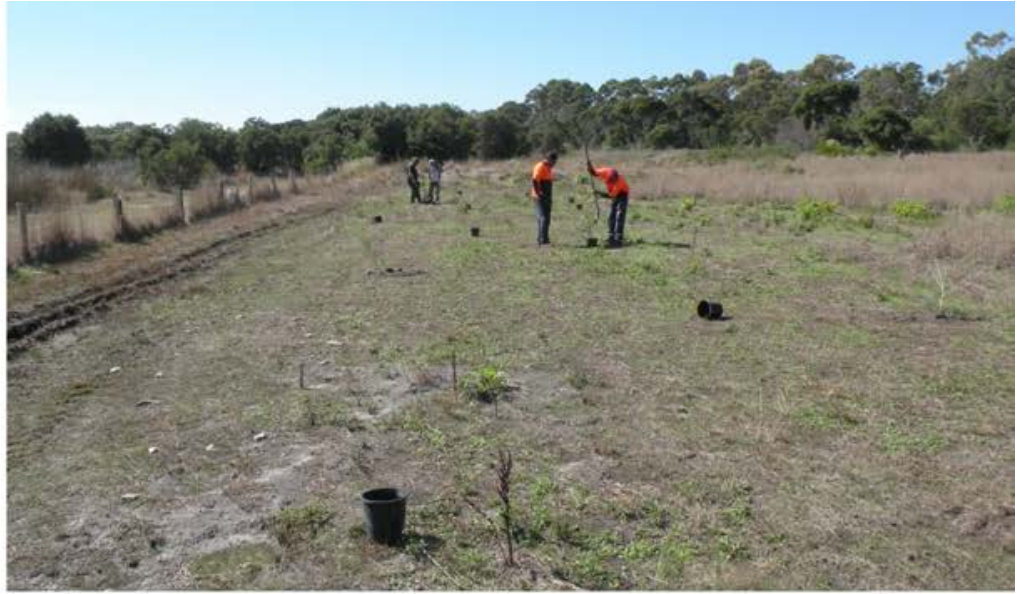

B

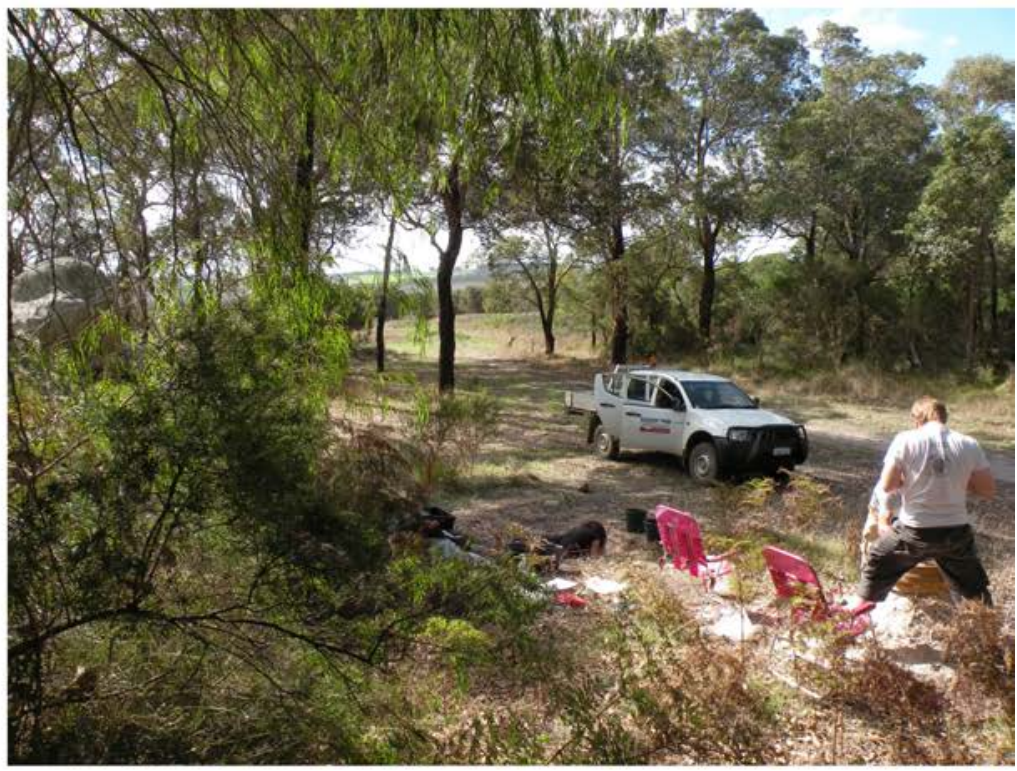

C

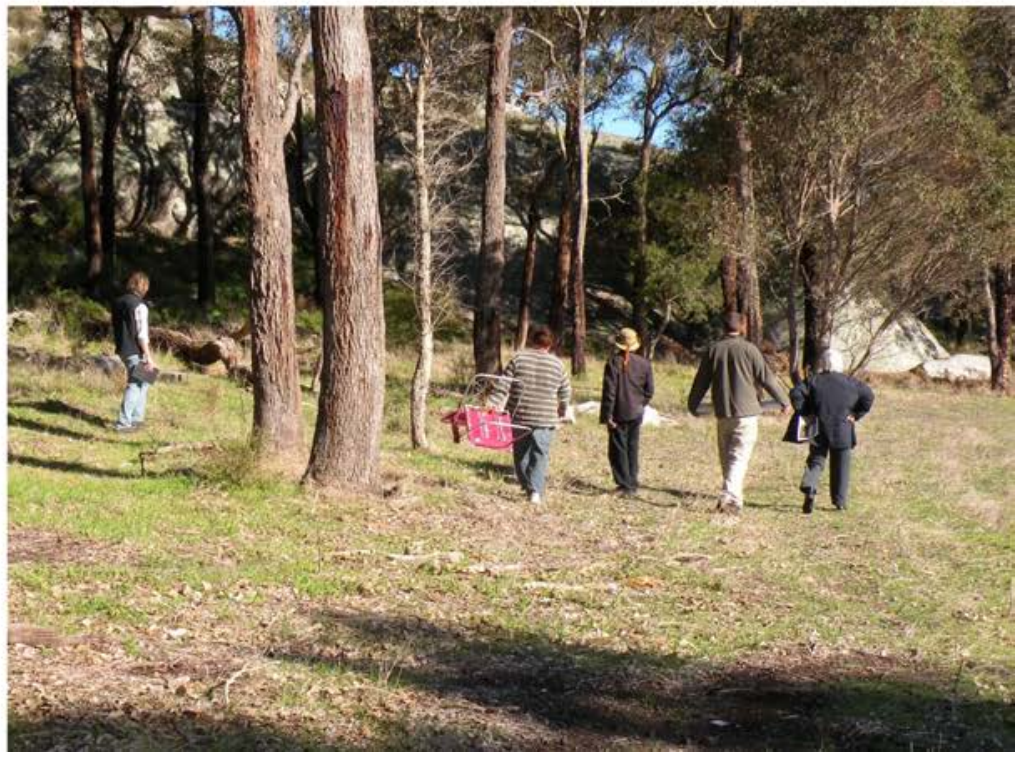

Figure 3. Indigenous conservation and land management training team undertaking (a) revegetation and weed control around the wetland (b) archaeological investigations, and (c) cultural/ecological mapping - occurring concurrently. 
At a broad level, the processes to be met in achieving the management plan targets were articulated within three main objectives that served to link NRM and CRM processes:

1. facilitate sustainable property management and traditional use;

2. maintain and enhance conservation values of the area; and,

3. foster community ownership of and responsibility for the area.

At a practical level, the AHRGAC approves and facilitates short heritage and natural resource management training courses on the property (delivered by a registered training provider), and works with local schools in conducting educational trips to examine the natural and cultural values. A weed control programme includes a re-vegetation component, often resourced by the regional NRM body. Restoration work is carried out by community members at the wetland, including seed collection/propagation, weed eradication, and revegetation (Figure 3). Another method of securing ownership and control was through access arrangements, whereby any person wishing to visit or work in the area (including consultants and land managers) is required to obtain approval from the Reference Group. Thus, there was not only a focus on achieving environmental and cultural heritage management outcomes, but the approach ensured the methods contributed to community ownership and sustainable development:

It's also about leadership, we are actually demonstrating some leadership in this regional community to say this is how we can do it, and these are the benefits for all of us. (Harley Coyne, pers. comm., 2010)

An additional component of the management plan centered on ongoing cultural mapping and monitoring, in order to integrate cultural and natural heritage management actions in a more strategic, regional manner. Its implementation is guided by the Traditional Owners and supported through partnership agreements linking local land management bodies, and centered on cultural mapping, landscape archaeology, and Indigenous knowledge. As the management plan continues to be implemented, it provides an ideal study area to develop and refine understandings of the integrated landscape. The next section explores this aspect of the project and develops an argument for embedding archaeological projects within NRM processes.

\section{The integration of landscape archaeology, Indigenous knowledge, and NRM}

A major aspect of the discussion with Traditional Owners was the suggestion of a landscape-level approach to management in order to ensure that the intrinsic links between cultural heritage and the wetland ecosystem were recognised. Quite often there is a discord between archaeological methods of site recording and analysis, and the Traditional Owner concept of the integrated cultural landscapes (Byrne 2008; Bradley 2008; Prangnell et al. 2010). Thus, this project required a method to explicitly examine the various components of this integrated cultural landscape and embed a process for assessing, documenting, and managing the associated values.

Natural resource management is the link in protecting and restoring cultural heritage places and values at a landscape level, or in Aboriginal terms 'caring for Country'. Just as Sullivan advocates for a cultural heritage management system at a national level, that "protects cultural landscapes at their fullest expression [or] in other words protects 'Country'" (Sullivan 2008); the approach adopted here seeks to do so at a local level, under the cultural leadership of Traditional Owners. Despite the applicability of NRM for such landscape approaches, quite often NRM strategies are developed without adequate strategic planning with regard to integration of CRM and NRM. This results in lost opportunities that can be achieved when these strategic connections are made: 
with the landscape, the holistic nature of Aboriginal culture means that issues relating to natural resource management are interlinked with those of cultural heritage management. (Windle and Rolfe 2002:35)

Thus, while the immediate actions of this project focused on the area of private land bordering the wetland - when it was purchased for the local community group arising from threat to specific heritage features - the strategic development of the project led to the implementation of a community management structure that extended across the entire wetland and surrounding areas, enacting NRM actions within a CRM framework. In this way the project attained a landscape focus within a strategically linked integration of CRM and NRM.

At a methodological level, this component involved cultural mapping occurring concurrently with on-ground restoration work. This also required additional assessment of both the ecological and cultural places and values throughout the wider area, within a cultural landscape methodology. A landscape approach allowed for the management of ecological values while assessing and protecting aspects of the cultural landscape as defined by the Traditional Owners. This approach prompts local knowledge about how the landscape has changed, and ideas on what should be done for dual natural and cultural heritage conservation. As Byrne and Nugent (2004:73) wrote: 'it is the landscape themselves that ought to be considered heritage, rather than discrete and dispersed 'sites' within them'.

Thus, the objective was not to analyse and document individual sites, but to explore networks of places to reveal interconnections that reflect movement of people and materials around the landscape. Traditional Owners and heritage specialists worked together to map the granite landform system surrounding the wetlands, while identifying appropriate mechanisms to ensure the restoration and protection of both the natural and cultural resources. This process also had direct outcomes for the wetland system and associated biodiversity values. For one example, the local knowledge pertaining to wild resource use and interconnections of places and landforms facilitates archaeological inquiry, as Green et al. have noted:

The environmental skills of people who have learned from the knowledge of many generations can add significantly to the way one reads a site and oral tradition can greatly enrich understanding of the meanings of places. (Green et al. 2003:369)

For this project, an ecological mapping and traditional ecological knowledge assessment was undertaken (Janicke 2010) at the same time as a landscape archaeology research project that began with the development of a CRM plan that included on-ground conservation work (Figure 3). The archaeological research component has since developed into a Masters level research project. This study aims to:

1. Examine the inter-relationships between the oral histories and archaeological landscape; and,

2. Establish a chronological framework for the area that examines both the formation of the wetland and changes in regional settlement patterns.

The investigation contributes to existing regional models which suggest the late Holocene period involved structured movements based on social and territorial boundaries, with seasonal movement between the coast (focused on the summer months) and inland areas (more dispersive use of the inland woodlands during winter). For instance, Dortch (1984:2002) suggests that past land use patterns involved seasonal movements linked to the availability of key resources, whereby groups most likely congregated on the coast during summer and autumn, largely dispersing inland during the winter months. The hypothesis here is that the Lake Pleasant View area was used as a congregative zone, whereby people would live in small family groups for most of the year, and seasonal gatherings of larger family and tribal groups would take place at certain times of the year when certain resources were available and abundant. 
The archaeological investigations included surveys and test excavations on the community owned/ managed property and archaeological surveys around the wetland and the surrounding region. These surveys resulted in the identification of an extensive archaeological signature associated with Lake Pleasant View and wetlands to the north. Surface stone artefact scatters were recorded and analysed on site across the property and wetland. Three test excavations were undertaken revealing relatively intensive use of this area over the last three thousand years (Figure 2, Table 1), with an assemblage somewhat equally divided between tool maintenance, manufacture and core reduction, with a number of formal implements (backed artefacts). The preliminary data supports the view that there was a relatively intensive past history of human occupation in this area, and the settlement-subsistence patterns were somewhat structured by the wetland, and serving as a movement corridor between the upland hills and coastal resources to the south. The wetland sites likely represent a larger occupation area with a range of integrated smaller sites in the surrounding hinterland used as part of logistical forays, with larger congregative sites at specific, more distant locations, such as Waychinicup (to the south) and the Three Sisters Nature Reserve (to the north). This is how the Traditional Owners describe the place (as briefly mentioned above).

Table 1. Radiocarbon dates obtained from three test excavations.

\begin{tabular}{|l|l|l|l|l|l|}
\hline Laboratory code & Test pit/spit & Depth $(\mathbf{c m})$ below mgs & $\mathbf{1 4 C}$ age (years BP) & $\mathbf{\delta 1 3 C}$ & Calibrated age BP (95\%) \\
\hline Wk-28164 & CM2_L2_S3.4 & 27 & $2562 \pm 30 \mathrm{BP}$ & $-21.9+/-0.2 \% 0$ & 2592 cal BP -2532 cal BP \\
\hline Wk-28165 & CM2_L2_S4.5 & $28-33$ & $2550 \pm 30 \mathrm{BP}$ & $-24.8+/-0.2 \% 0$ & 2580 cal BP -2520 cal BP \\
\hline Wk-28494 & CM3_L2_S3.4 & 31 & $3140 \pm 30 \mathrm{BP}$ & $-23.9+/-0.2 \% 0$ & 3170 cal BP -3110 cal BP \\
\hline Wk-27271 & LPV_2_L4_S3 & 29 & $3009 \pm 30 \mathrm{BP}$ & $-3.9+/-0.2 \% 0$ & 3039 cal BP -2979 cal BP \\
\hline
\end{tabular}

Source: Author's research.

Here, the archaeological investigations complement, and are complemented by, the ethnographic and local knowledge of the area, and also an ecological assessment. Thus, the heritage complex is of important archaeological significance given that current knowledge largely pertains to the coastal zone and Albany area, and so more detailed investigations throughout this corridor are shedding light on patterns of the regional heritage landscape. It is also providing baseline data that is required for effective heritage landscape management, in the analysis of wetland formation, human impacts such as firing, and patterns of human-environmental relations over time and across space. Most importantly, the study links archaeological data to oral histories that also feed into the ongoing management actions. This mirrors other similarly deigned community heritage and NRM projects, such as that reflected in this statement from Ross et al.:

From our field experiences, we have learned that Indigenous know-how is a form of 'local knowledge', intricately bound to particular communities and places as well as to whole ways of life. (Ross et al. 2010:34)

\section{Discussion}

The heritage place of specific focus here is valued as a significant cultural place embedded with the actions and continued presence of the Traditional Owners and the actions of their ancestors. In this way it maintains and displays the Traditional Owner's connection to the past and present, and contains meaning at a number of different levels. From a management perspective, these intangible values are included within the landscape-level protection and maintenance of the integrity of the features and places associated with this property, the wetland, and surrounding landscape. The place is also a central component to community identity as it provides a sense 
of belonging, historical association, and is part of the ongoing cultural practice of 'caring for Country'. This practice is an important aspect of cultural heritage, with the notion that heritage is not static or fixed, but requires active participation in heritage management. Thus, the project is important in a contemporary context for facilitating 'caring for Country' in a region where access to land is limited, and provides for a more socially-relevant cultural heritage management project, as articulated by Byrne et al.:

The fact that a local community, Indigenous or non-Indigenous, may live in a landscape which is scattered with places where physical traces of past occupation are present, does not in itself create an identity association between those traces and the community. The association comes about through certain activities. These may include the work carried out to protect the traces from erosion or vandalism, the taking of visitors out to see the traces as part of a local cultural tourism venture. It may consist of a community member talking to a class at the local school about the traces, or it may consist simply of the reminiscences about the place which appear in an autobiography written by a community member. (Byrne et al. 2003:66-67)

As a landscape management project, the on-ground work entailed incorporation of traditional ecological knowledge with on-ground management and restoration of land. Not only does this collaboration assist in meeting NRM aims in the region (recognised as a high priority for biodiversity, land and water conservation), the work on this land serves as a model for community-driven land management ('caring for Country') that has environmental, social and cultural heritage outcomes. The regional NRM body has partnerships with several major land management and conservation groups that provides assistance to the AHRGAC for on-going management, and directly and indirectly assists in building the capacity of the local community to monitor and manage the land under contemporary land management structures, as Little (2007:2) states:

A socially useful heritage can stimulate and empower both local community members and visitors to make historically informed judgments about heritage and the ways that we use it in the present.

The clear heritage management framework endorsed as part of this assessment was to continue to foster the existing ongoing partnership and support for future monitoring and management of the property. The original relationships were expanded as specific project outcomes were delivered (on-ground conservation of the wetland ecology and cultural heritage assessments) in efforts to secure long-term resources for community management and development of a structured management framework that includes integration with other key land management authorities.

This project articulated the clear role of archaeology as a useful medium for all negotiations, the instrument for on-ground actions and community engagement (training/employment), linking the divide between natural and cultural heritage management, and developing a landscapelevel research programme that investigates the inter-connections between oral history and the archaeological record - itself a means for community empowerment as the lead agent in sustainable property management via research and land care under customary guidance ('caring for Country'). The project is a practical example of what we understand collaborative Indigenous archaeology to be:

Within collaborative Indigenous archaeology, this perspective requires that archaeologists consider Indigenous perspectives at many times other than during the final interpretation or at the moment of doing 'public outreach' to a descendant community. These perspectives should be acknowledged and often embedded at all stages of the archaeological process, from project formulation to field methods, from excavation recovery to laboratory analysis, from interpretation to writing. In particular, these 
incorporations should be fundamental elements of archaeological field schools that focus on Indigenous pasts, for in these complex intersections of teaching and research lies real potential to change the discipline.

(Silliman 2008:3-4)

\section{Conclusion}

Our Elders are heavily involved in all things from start to finish. We have had some major projects, some minor projects; it has really created this sense of ownership, of wanting to be involved, of loving the place and wanting to do the right thing to do by it. It has given them back a real sense of pride, I think. (Aunty Vernice Gillies, pers. comm., 2011)

With increasing recognition of the overlap between natural and cultural heritage management, this project demonstrates the potential to implement landscape-scale projects that result in integrated holistic outcomes at a community level. The approach advocated here was to establish a cultural heritage management framework that allows ongoing study of the local archaeology and ecology while land care activities are undertaken at a regular basis, including monitoring of the area's natural and cultural values. The programme continues to provide many community days, ongoing research, formal training projects, that all contribute to a greater understanding of the natural and cultural landscape and community wellbeing. It is argued here that it was the combination of skills provided by both the Traditional Owners and the archaeological team that fostered integration of community objectives with heritage agency and NRM targets; facilitated the engagement process; coordinated on-ground actions; and was able to deliver documents and reports outlining the dual management actions and technical detail specific to the natural and cultural values.

At the same time, it was only through the structured, developed and community mechanisms of control and ownership that allowed the ongoing, successful development of this project and provided a platform, not just for archaeological investigation, but for archaeology to make a very real contribution to the present and the future through living heritage and community NRM. It demonstrates the identified potential and value of this type of collaborative approach for any archaeology project that many researchers have increasingly been advocating and implementing, as for example, Marshall (2002:218):

The kind of collaborative research fostered by community archaeology will be crucial if archaeology is to have a future. It is the only way Indigenous heritage, descendant communities and other local interest groups will be able to own the pasts archaeologists are employed to create.

Where the Traditional Owners were once frustrated and resentful of the lack of engagement and involvement in previous management regimes, the AHRGAC now approach all agencies and organisations that may have an interest in assisting their efforts for on-ground conservation and management of both natural and cultural heritage values associated with this area. It directly challenges existing structures and issues that cripple many joint-management negotiations and plans across Australia, as Ross et al. note:

In the name of conservation and the protection of biological diversity, Indigenous peoples are being systematically excluded from lands and resources they occupied, utilised, and indeed protected for generations. Labelled poachers and trespassers in newly created parks, wildlife sanctuaries and other protected and often fenced areas, part of the problem, rather than a solution, Indigenous peoples find it increasingly hard if not impossible to participate meaningfully in the sustainable management of their own ancestral territories. (Ross et al. 2010:29) 
This project has led to the development of a structure whereby land management agencies and organisations seek to become involved in this community owned and managed area. In the protection of archaeological resources and heritage values associated with this cultural landscape, management processes here focused on the dual conservation of the natural and cultural features. In many ways, this simply means integrating the actions required to maintain the ecological and biodiversity values of the local system with the integrated cultural heritage landscape. However, under this structure of understanding heritage as social activity, it provided direct opportunities for community-driven rehabilitation and management. The methods by which the process was to be implemented resulted in a long-term community-based heritage management programme. The activities served to protect the cultural values associated with these places, in recognising that caring for Country is an integral component of identity and cultural vibrancy. In general, the conservation works associated with these properties are aimed at sustainable land use, erosion and salinity control, biodiversity protection and waterways protection. These actions are also those that are required to ensure the protection and conservation of the region's non-renewable cultural resources and reconnect aspects of a fragmented, threatened cultural heritage landscape. This paper has argued that to effectively achieve these integrated outcomes, an understanding of heritage as social activity is required, and the integration of CHM and NRM methods beneath a community-owned/managed structure is perhaps the only effective platform to achieve practical outcomes in this regard. There is great potential for landscape-level archaeological projects to contribute much toward active heritage management, conservation, and sustainable outcomes when developed in partnership with Indigenous communities, and especially when NRM methods and processes are integrated into each stage of a project.

\section{Acknowledgements}

This project and paper was developed under the direction and guidance of the Menang Elders and wider community who have welcomed us into their Country, Land and Heritage. The Albany Heritage Reference Group Aboriginal Corporation provides much of the direction and energy to the project, along with a number of other projects in the Albany region. The project was served greatly by a number of younger community members and project officers, especially Jerry Narkle, Ryan Humphries, and Iszaac Webb, along with a number of trainees and volunteers from the Albany community. South Coast Natural Resource Management Inc. (especially project officer Shandell Cummins) continues to provide support to the projects, as does the team at the Department of Indigenous Affairs (Southern Region). The Centre of Excellence in Natural Resources Management, the team at the Department of Water (Albany), Great Southern TafeWA, and the Many Peaks Primary School, have all provided great technical and community support to various components of this project. There are many different facets to this project led by the Traditional Owners that are not covered here, as this paper has only focused on several elements related to the role of archaeology and the integration of natural and cultural heritage management. We thank the reviewers Annie Ross and Mick Morrison, as well as the editors of Terra Australis, who helped a great deal towards getting this paper into shape.

\section{References}

Anaya, J. 2010. Report by the Special Rapporteur on the situation of human rights and fundamental freedoms of Indigenous people: Addendum - Situation of Indigenous peoples in Australia. UN General Assembly, Human Rights Council, Fifteenth Session, Agenda Item 3.

Aplin, G. 2002. Heritage: Identification, conservation, and management. Oxford University Press, Melbourne. 
Bradley, J. 2008. When a stone tool is a dingo: Country and relatedness in Australian Aboriginal notions of landscape. In: David, B. and Thomas, J. (eds), Handbook of landscape archaeology, pp. 633-637. Left Coast Press, Walnut Creek.

Brown, S. 2008. Mute or mutable: Archaeological significance, research and cultural heritage management in Australia. Australian Archaeology 67:19-30.

Byrne, D. 2008. Counter-mapping in the archaeological landscape. In: David, B. and Thomas, J. (eds), Handbook of landscape archaeology, pp. 609-616. Left Coast Press, Walnut Creek.

Byrne, D., Brayshaw, H. and Ireland, T. 2003. Social significance: A discussion paper. Research Unit, Cultural Heritage Division, New South Wales National Parks and Wildlife Service, Hurstville.

Byrne, D. and Nugent, M. 2004. Mapping attachment: A spatial approach to Aboriginal post-contact heritage. Department of Environment and Conservation, Hurstville.

Colley, S. 2007. University-based archaeology teaching and learning and professionalism in Australia. World Archaeology 36:2:189-202.

Dortch, C.E. 1984. Devil's Lair: a study in prehistory. Western Australian Museum, Perth.

Dortch, C.E. 2002. Modelling past Aboriginal hunter-gatherer socio-economic and territorial organisation in Western Australia's lower South-west. Archaeology in Oceania 37:1-21.

Environment Australia. 2001. A directory of important wetlands in Australia (3rd edition). Environment Australia, Canberra.

Green, L.F., Green, D.R., David, R. and Góes Neves, E. 2003. Indigenous knowledge and archaeological science: The challenges of public archaeology in the Reserve Uaçá. Journal of Social Archaeology 3(3):366-398.

Guilfoyle, D.R., Bennell, B., Webb, W., Gillies, V. and Strickland, J. 2009. Integrating natural resource management and Indigenous cultural heritage: A model and case study from south-Western Australia. Heritage Management 2(2):149-176.

Guilfoyle, D.R., Webb, W., Webb, T. and Mitchell, M. 2011. A structure and process for 'working beyond the site' in a commercial context: A case study from Dunsborough, southwest Western Australia. Australian Archaeology 73:25-32.

Hemming, S. and Rigney, D. 2010. Decentring the new protectors: Transforming Aboriginal heritage in South Australia. International Journal of Heritage Studies 16:1-2,90-106.

Janicke, G. 2010. Lake Pleasant View ecological assessment. Report No. CENRM 109. Centre of Excellence in Natural Resource Management, University of Western Australia, Perth.

Little, B.J. 2007. Archaeology and civic engagement. In: Little, B.J. and Shackel, P.A.(eds), Archaeology as a tool of civic engagement, pp. 1-22. Altamira Press, Walnut Creek.

Marshall, Y. 2002. What is community archaeology? World Archaeology 34(2):211-19.

Morse, K. 2009. Emerging from the abyss: Archaeology in the Pilbara Region of Western Australia. Archaeology in Oceania 44: supplement.

Moser, S., Glazier, D., Phillips, J.E., Nemr, L.N., Mousa, M.S. and Aiesh, R. 2002. Transforming archaeology through practice: Strategies for collaborative archaeology and the Community Archaeology Project at Quseir, Egypt. World Archaeology 34(2): 220-248. 
The Open Mind Research Group. 2006. State of Indigenous cultural heritage - A survey of Indigenous organisations. A report for the Department of Environment and Heritage, Canberra.

Prangnell, J., Ross, A. and Coghill, B. 2010. Power relations and community involvement in landscapebased cultural heritage management practice: an Australian case study. International Journal of Heritage Studies 16 (1):140-155.

Ross, A., Sherman, K.P., Snodgrass, J.G., Delcore, H.D. and Sherman, R. 2010. Indigenous peoples and the collaborative stewardship of nature: Knowledge binds and institutional conflicts. Left Coast Press, Walnut Creek.

Silliman, S.W. 2008. Collaborative Indigenous archaeology: Troweling at the edges, eyeing the center. In: Silliman, S.W. (ed.), Collaborating at the trowel's edge: Teaching and learning in Indigenous archaeology, pp.1-21. University of Arizona Press, Tuscon.

Sullivan, S. 2008. More unconsidered trifles? Aboriginal and archaeological heritage values: Integration and disjuncture in cultural heritage management practice. Australian Archaeology 67:107-115.

Windle, J. and Rolfe, J. 2003. Valuing Aboriginal cultural heritage sites in central Queensland. Australian Archaeology 56:35-41. 